\title{
The cognitive neuropsychological phenotype of carriers of the FMR1 premutation
}

\author{
Jim Grigsby ${ }^{1,2^{*}}$, Kim Cornish ${ }^{3}$, Darren Hocking ${ }^{4}$, Claudine Kraan ${ }^{3}$, John M Olichney ${ }^{5,6}$, Susan M Rivera ${ }^{5,7,8}$, \\ Andrea Schneider ${ }^{5,8}$, Stephanie Sherman ${ }^{9}$, Jun Yi Wang ${ }^{5,10}$ and Jin-Chen Yang ${ }^{5,6}$
}

\begin{abstract}
The fragile X-associated tremor/ataxia syndrome (FXTAS) is a late-onset neurodegenerative disorder affecting a subset of carriers of the FMR1 (fragile $X$ mental retardation 1) premutation. Penetrance and expression appear to be significantly higher in males than females. Although the most obvious aspect of the phenotype is the movement disorder that gives FXTAS its name, the disorder is also accompanied by progressive cognitive impairment. In this review, we address the cognitive neuropsychological and neurophysiological phenotype for males and females with FXTAS, and for male and female unaffected carriers. Despite differences in penetrance and expression, the cognitive features of the disorder appear similar for both genders, with impairment of executive functioning, working memory, and information processing the most prominent. Deficits in these functional systems may be largely responsible for impairment on other measures, including tests of general intelligence and declarative learning. FXTAS is to a large extent a white matter disease, and the cognitive phenotypes observed are consistent with what some have described as white matter dementia, in contrast to the impaired cortical functioning more characteristic of Alzheimer's disease and related disorders. Although some degree of impaired executive functioning appears to be ubiquitous among persons with FXTAS, the data suggest that only a subset of unaffected carriers of the premutation - both female and male - demonstrate such deficits, which typically are mild. The best-studied phenotype is that of males with FXTAS. The manifestations of cognitive impairment among asymptomatic male carriers, and among women with and without FXTAS, are less well understood, but have come under increased scrutiny.
\end{abstract}

Keywords: Fragile X-associated tremor/ataxia syndrome, FXTAS, FMR1, Fragile X, Executive function, Cognition disorders, Fragile X premutation

The fragile X-associated tremor/ataxia syndrome (FXTAS) is a late-onset neurodegenerative disorder associated with trinucleotide (CGG) repeat expansions of the FMR1 (fragile X mental retardation 1) gene. The most obvious signs and symptoms of FXTAS include action tremor, ataxia, parkinsonism, and peripheral neuropathy, but circumscribed aspects of cognition are impaired as well. FXTAS affects persons who have CGG expansions in the premutation range (that is, 55-200 CGG repeats), as opposed to fragile $\mathrm{X}$ syndrome (FXS), which is associated with the full mutation (over 200 CGG repeats) at FMR1. FXTAS and FXS have very different phenotypes, the latter

\footnotetext{
* Correspondence: jim.grigsby@ucdenver.edu

'Department of Psychology, University of Colorado Denver, Denver, CO, USA ${ }^{2}$ Department of Medicine; Division of Health Care Policy and Research, University of Colorado School of Medicine, Aurora, CO, USA

Full list of author information is available at the end of the article
}

involving an early childhood-onset intellectual development disorder, often with autistic features, while FXTAS affects persons who previously were cognitively normal, in the sixth or seventh decade of life.

The basic cognitive phenotype of FXTAS is relatively well understood. However, at the time of the initial identification of FXTAS, it was thought that women who carry the premutation might have little susceptibility to the disorder, perhaps because of the presence of a normal allele among female heterozygotes. Penetrance, and possibly expression, is significantly higher in males than females, and because men with FXTAS were more readily identified than females with FXTAS, they have been more extensively studied, and more is known about the nature, severity, and course of cognitive impairment among men. The objective of this paper is to review the cognitive neuropsychological phenotype of carriers of the fragile $\mathrm{X}$ 
(FX) premutation, both those who have FXTAS, and those who are clinically unaffected.

\section{Review \\ Cognitive neuropsychological phenotype among males with FXTAS}

Since the first case reports [1], it has been apparent that FXTAS is associated with a progressive decline in cognitive functioning. Although deficits in several aspects of cognition have been reported [2-4], the evidence appears to support the idea that the primary disorder is a disturbance of executive functioning (EF) [5]. The executive functions represent an important subset of cognitive abilities. In essence, EF is the capacity for the autonomous regulation of one's own behavior and attention. Fuster [6,7] maintains that EF represents the temporal organization of behavior, allowing one to initiate purposeful behavior, and to inhibit irrelevant or inappropriate activity.

Early studies of FXTAS reported deficits in EF, working memory, speed/capacity of information processing and learning $[2,3,8]$. The first systematic study of cognition essentially replicated the early results, and showed that males with FXTAS ranged from high average through severely impaired in these areas of functioning, the group mean representing moderate impairment [4]. FXTAS patients performed significantly worse on several EF measures than did a sample of controls.

General cognitive functioning among FXTAS patients is typically impaired [2-4], although intelligence quotient (IQ) scores are in the normal range. In the largest study of men with FXTAS to date, mean Wechsler Adult Intelligence Scale-III (WAIS-III) verbal and performance (nonverbal) IQ scores were 106.6 and 97.7, respectively [4]. Lower performance IQs may be a function of the greater dependence of the nonverbal scale on processing speed, working memory, and EF [5]. On the Mini Mental State Exam [9], a measure of general mental status, the difference in mean scores of FXTAS patients and controls was statistically, but not clinically, significant (27.6 vs 29.2). Nevertheless, a subset of individuals with FXTAS - most with advanced disease demonstrates frank dementia $[10,11]$. Performance on measures of declarative memory is impaired, likely reflecting the effects of executive dysfunction (that is, problems with active learning and active retrieval) rather than a primary memory disorder.

Neither expressive nor receptive language appears to be affected in FXTAS. Repetition, naming, reading, comprehension of complex material, and following spoken commands differed little across groups. Performance on most visuospatial measures was unimpaired, although men with FXTAS performed more poorly than controls on the WAIS-III Block Design subtest - probably in association with reduced processing speed and deficient organizational ability $[4,5]$.

In a study of functional status (basic physical functioning, activities of daily living, and instrumental activities of daily living), men with FXTAS, but not unaffected carriers, were impaired in all three functional areas. This effect appeared to be mediated by both executive and motor functioning [12].

It is not possible to localize the cognitive deficits of FXTAS to a specific brain region. Although the eventrelated brain potential (ERP) studies of Yang and colleagues $[13,14]$ may implicate prefrontal cortex, EF is a widely distributed functional system that also may be affected by lesions of other areas, in particular the cerebellum $[15,16]$. To a large extent, FXTAS is a white matter disease [17-19], and the cognitive phenotype observed among men with FXTAS is similar to what has been called white matter dementia $[16,20,21]$, in which the extent of executive deficits is correlated with the burden of white matter abnormalities distributed throughout the brain [22].

\section{Cognitive neuropsychological phenotype among females with FXTAS}

The manifestation of neuropsychological signs and symptoms in female carriers can be diverse with low penetrance of FXTAS and milder phenotypes than those observed in males. Based on current diagnostic criteria, estimates suggest that as few as 8 to $16 \%$ of female carriers will develop FXTAS [23,24]. Moreover, in comparison with males, the onset of FXTAS for females tends to occur later in life, and is anatomically less severe, with a lower penetrance of middle cerebellar peduncle and pontine white matter hyperintensities, less brain atrophy, and less severe white matter disease overall $[25,26]$. This milder phenotype is thought to stem from protective mechanisms associated with $\mathrm{X}$-inactivation and hormonal differences [27-29]. However, this notion does not have full support [23].

Although studies of FXTAS among males suggest that the presenting cognitive profile is predominantly one of executive dysfunction, there is a dearth of research systematically examining the cognitive profile in females with FXTAS. Indeed, existing studies have been inconsistent in demonstrating interrelationships between neuropsychological profiles, imaging correlates, and standardized clinical measures [25,30-32]. Recent neuropsychological and neurophysiological studies have shown that females with FXTAS present with executive dysfunction as the primary cognitive impairment, similar to the male cognitive profile [32,33]. Most significantly, a neuropathological case study series reported dementia in 4 of 8 autopsied female carriers, in conjunction with an increased number of intranuclear inclusions, suggesting that dementia may be 
more prevalent than previously thought in women with FXTAS [34].

With regard to psychological symptoms in females with FXTAS, neuroimaging studies have shown an association between hippocampal abnormalities and anxiety in unaffected carriers [35]. Although these results suggest that females show mild early-onset neuropsychological phenotypes irrespective of FXTAS, further research is needed to understand the synergistic effects of age, psychological vulnerability, and risk factors for FXTAS. Indeed, given that prevalence rates for probable attention deficit hyperactivity disorder ( 4.5 to $25 \%$ ), anxiety (20.9 to $30 \%$ ) and depression (14.03 to $47.3 \%$ ) far exceed the risk of FXTAS (8 to $16 \%$ ) in women [23,24,36-40], the molecular and environmental factors contributing to gender-divergent trajectories are yet to be fully characterized.

\section{Neurophysiology of cognition in FXTAS}

Much of what is known of the cognitive electrophysiology of FXTAS patients has been found using the ERP technique. Cognitive ERPs, primarily representing the summated activity of post-synaptic potentials, offer an excellent non-invasive measure for characterizing different stages of cognitive processing due to their millisecond-level temporal resolution [41].

While performing an auditory "oddball" task requiring dual-response, a predominantly male group of participants with FXTAS had longer N100 latency and smaller P200 amplitude than normal controls, indicating some impairment of early-stage attention [13]. Furthermore, these individuals showed decreased amplitude and prolonged latency of P300, a component believed to reflect late-stage "controlled" attention and working memory updating. P300 abnormalities in these FXTAS patients were observed over fronto-central and parietal scalp, and the frontal P300 measures correlated with executive function test scores, working memory, FMR1 mRNA level, and CGG repeat length [13]. The frontal P300 impairments have been replicated in a second study including 29 female FXTAS patients, with correlations also obtained between P300 measures and executive function, working memory, and information processing speed [32]. Therefore, it has been suggested [13,32] that abnormal fronto-parietal attentional network dynamics may play an important role in executive dysfunction, the primary cognitive impairment in FXTAS [5].

Verbal memory and language processes in FXTAS also have been probed via an ERP word repetition paradigm/ category judgment task, in which semantically congruous (50\%) and incongruous words are repeated after an interval of between 10 and 140 seconds. This word repetition paradigm was employed in the first published ERP study of FXTAS [42], in which it was demonstrated that FXTAS patients had a significantly reduced N400 word repetition effect (new-old incongruous words), an electrophysiological marker of semantic processing load and implicit memory previously shown to be sensitive to early Alzheimer's disease (AD) [43,44]. Unlike persons with $\mathrm{AD}$, however, FXTAS patients displayed a preserved P600 word repetition effect (new-old congruous words) that has been linked to episodic/declarative memory. Yang and colleagues [45] examined a group of FXTAS females and found a relatively normal N400 repetition effect, but decreased N400 congruity effect (incongruous-congruous new words), suggesting abnormal semantic activation and/or semantic network disorganization, which they attributed to executive dysfunction.

Electrophysiology has also been used to assess the effectiveness of potential pharmacologic treatments for FXTAS. Because the N400 measures are sensitive to both FXTAS and glutamatergic signaling [46], the method was utilized to evaluate the treatment effects of memantine (an uncompetitive N-methyl-D-aspartate receptor antagonist approved for treatment of $A D$ ) in a substudy of the first placebo-controlled, double-blind, randomized clinical trial in FXTAS $[47,48]$. Results indicated a tendency toward larger N400 repetition effect amplitude after 12 months on memantine, and patients who had increased N400 repetition effects showed the largest improvements in cuedrecall of the experimental verbal stimuli. Although the main memantine trial in FXTAS showed no significant treatment effects on the primary outcome measures of executive function and intention tremor [48], the ERP results suggest the need for further studies of memantine and/or other therapeutic agents for this neurodegenerative disorder, which currently has no proven therapies.

There is a paucity of other published studies on the central neurophysiology of FXTAS, with a few case report studies showing abnormal electroencephalogram (for example, [49]). One noteworthy study of people with FXTAS found decreased auditory prepulse inhibition [50], an electromyography index of sensorimotor gating also affected in FXS. Thus, abnormalities of the frontal P300, N400 brain potentials, and prepulse inhibition should all be considered putative electrophysiological trait markers of the FMR1 premutation.

\section{Cognition among unaffected male premutation carriers}

The cognitive phenotype of unaffected male carriers of the FMR1 premutation, although not as extensively researched as that of males with FXTAS, is relatively well understood. There is general agreement that some males demonstrate a progressive age-related decline in executive function skills that is greater than that displayed by males with a normal allele, matched on age and IQ. In a series of published papers, Cornish and colleagues have isolated a subtle age-related decline of inhibitory control (as measured by the Haylings Task) and 
working memory (as measured by the Letter-Number sequencing task [51-53]) that begins in early adulthood and continues across the lifespan. Interestingly, males with more than 100 CGG repeats may be especially at risk for cognitive difficulties [51]. Grigsby and colleagues [4] reported a similar profile of difficulties in executive functioning, with unaffected carriers performing worse than normal-allele controls on a composite measure of $\mathrm{EF}$, and on immediate and delayed recall on the Logical Memory subtest of the Wechsler Memory Scale-III [54].

In addition, recent functional magnetic resonance imaging (fMRI) data indicate changes in prefrontal activity in premutation carriers, irrespective of FXTAS diagnosis, during performance of a working memory task [55]. These preliminary findings provide the first evidence to suggest the involvement of specific brain regions associated with neural networks mediating EF among persons in the premutation range, with or without FXTAS. However, several studies have failed to find differences in cognitive performance between non-affected male carriers and typically developing males [56,57]. One possibility is that relatively small samples sizes and variability in age range and CGG repeat distribution across studies may explain some of the discrepant findings.

To address this concern, Hunter and colleagues [58] combined their samples to form a multi-center database with 100 asymptomatic premutation males and 216 noncarriers. In line with previous reports by Cornish and Grigsby $[4,5,51]$, analyses across shared measures of inhibition and working memory detected very subtle differences (which were of minimal clinical significance) on a measure of response inhibition (Stroop task), but on no other cognitive measures. Taken together, current findings provide evidence of a subtle, suboptimal level of cognitive performance among a subset of unaffected carriers, involving mild deficits in inhibition and working memory among a subset of male carriers, results which are relatively consistent with earlier research [59-61].

\section{Cognition among unaffected female premutation carriers}

Although the presence of a neuropsychological phenotype in unaffected female premutation carriers is controversial [56,57], recent studies have shown that a subset of young adult female carriers exhibit subtle deficits in executive function and inhibitory control $[33,37,62]$, visuospatial processing [63,64], mathematical reasoning [65,66], and tasks dependent on processing speed and working memory [32]. It has been argued that targeted, domain-specific measures may more sensitively identify subtle neurocognitive deficits than gross neuropsychological tests [67]. Indeed, more targeted measures have identified enhanced psychomotor ability $[68,69]$, motor programming deficits [70], increased balance and memory problems [70,71], and age- and CGG-dependent changes in the attentional demands of postural control [72]. Collectively, these findings point to early at-risk phenotypic features suggesting cerebellar dysfunction in a subgroup of female premutation carriers; however, prospective longitudinal studies will be needed to determine who will eventually develop cognitive impairment and neurodegenerative decline.

With regard to the neuropsychiatric phenotype, it has been shown that a subgroup of women who carry the FMR1 premutation, but who do not have FXTAS, may also be more vulnerable to elevated symptoms of anxiety and depression compared to the general population $[40,73,74]$. At least in part this may be the result of genetic variation (for example, CRHR1 polymorphisms and release of cortisol) moderating the stress of raising a child with FXS $[75,76]$. However, one recent study has shown that poorer inhibitory control and working memory are associated with elevated social anxiety, depression, and attention deficit hyperactivity disorder (predominantly inattentive symptoms) among women with the FMR1 premutation [37].

These data are novel in that they indicate early changes within frontally-mediated networks that may increase the risk of neuropsychiatric dysfunction. However, evidence for a contribution by other factors, such as expanded CGG repeats, and reproductive history in depressive female carriers, and anxiety symptoms in female carriers, has been inconsistent $[37,75,76]$. A recent study using more detailed clinical interviews from the Diagnostic and Statistical Manual of Mental Disorders, Fourth Edition has provided evidence that comorbid depressive and anxiety disorders are associated with significantly expanded CGG repeats, but not with reproductive or menstrual history [77]. Thus, a complex set of factors may contribute to executive and neuropsychiatric dysfunction in female carriers, involving genetic and epigenetic factors, caregiver burden, hormonal changes, and hypothalamic-pituitaryadrenal axis function. The precise relationships among these factors remain unclear.

\section{Neuroimaging and cognition}

The FMR1 gene and its protein product, fragile $\mathrm{X}$ mental retardation protein (FMRP), are expressed in brain areas important for high-level cognitive functioning [78,79]. Consequently, both subtle FMRP deficit and excessive FMR1 mRNA may affect the brain during development and aging in the FMR1 premutation, which ultimately lead to the cognitive phenotype in FX premutation carriers. Neuroimaging is a useful tool for non-invasive investigations of the impact of the FMR1 premutation on the brain and neural substrates underlying the cognitive deficits. Two main imaging modalities provide complementary insights into the mechanisms: functional MRI, which examines brain activation during cognitive tasks, and structural 
MRI, which provides a quantification of volume, morphometry, and white matter structural integrity/connectivity.

Consistent with the FMRP expression profile in the brain [80], both functional and structural MRI studies have shown a dose-response of FMR1 gene expression on brain regions important for working memory. In a functional MRI study examining verbal working memory in male and female premutation carriers [55], reduced activation was observed in the right inferior frontal cortex and left premotor cortex in both asymptomatic premutation carriers and carriers with FXTAS. Reduced activation was found in right premotor/inferior frontal cortex in the FXTAS group. The reduced activation in the right inferior frontal cortex exhibited a significant correlation with high lymphocytic FMR1 mRNA levels. In a structural MRI study [80] of male premutation carriers, while individuals with FXTAS showed diffuse gray matter loss most prominent in areas important for working memory (including prefrontal cortex, anterior cingulate cortex, and cerebellum) only the anterior cerebellar vermis and hemisphere displayed volume loss in those premutation carriers without FXTAS. Importantly, the reduced gray matter density of the inferior frontal and anterior cingulate cortices correlated significantly with low working memory performance, and the reduced gray matter density in the dorsomedial frontal cortex correlated with long CGG repeat length in premutation carriers.

Functional MRI studies have also revealed differences in brain activation in young adult premutation carriers asymptomatic for FXTAS, even where subtle differences in cognition cannot be measured by standard behavioral techniques. In a study of delayed recall memory, premutation carriers showed no deficits (relative to control participants) in ability to recall pairings on an associative memory task a day later, but were found to exhibit reduced left hippocampal activation, and activity in the left hippocampus was also negatively correlated with both FMR1 mRNA level and psychiatric symptomatology [81].

Likewise, in a study examining magnitude estimation processing, young asymptomatic adult carriers showed significantly attenuated bilateral intraparietal sulcus (IPS) activity that is commonly associated with the numerical distance effect (that is, greater effort/brain activation when the two displays to be compared are closer in numerosity), despite comparable behavioral task performance with the control group [82]. While both elevated FMR1 mRNA and increased CGG repeat expansion were associated with reduced IPS activation, the results of multiple regression suggested that increased CGG repeat size was the primary contributor to aberrant IPS function.

\section{Molecular mechanisms of FXTAS}

Although the data suggest that FXTAS may result from a toxic gain of function associated with excessive levels of FMR1 mRNA, the mechanism, and variables that influence it, remain unclear [83]. Although CGG repeat size in the premutation range is a diagnostic indicator and genetic marker for those who may develop FXTAS, repeat length predicts only a portion of risk and severity of FXTAS $[84,85]$, and there are other yet unidentified factors involved. Repeat length does not elucidate the mechanism of cellular or central nervous system pathology, or the relationship of cellular pathology to clinical disease.

\section{Treatment of FXTAS}

There are as yet no effective therapies for the treatment of FXTAS. As noted previously, one 12-month randomized controlled trial of memantine showed no difference from placebo on measures of tremor severity and executive functioning [48]. The limited literature is based largely on case studies (for example, [86]) and treatment has largely been directed toward symptom amelioration, with inconsistent results $[87,88]$.

\section{Conclusion}

The cognitive phenotype of FXTAS for both sexes appears to be characterized by a progressive impairment of executive functioning, working memory, and speed of information processing. This is characteristic of the pattern observed in fronto-cerebellar and white matter disease. The degree of impairment may become severe, and in advanced stages people with FXTAS may have very significant cognitive problems, even demonstrating problems ordinarily associated with cortical disorders. The dysexecutive syndrome that accompanies FXTAS appears to play a significant role, along with the movement disorder, in a significant decline in functional independence, and the development of psychiatric symptomatology.

Among carriers of the FMR1 premutation who do not have FXTAS, the data suggest that a subset of individuals has mild executive impairment. Whether the cognitive deficits shown by these people indicate preclinical FXTAS, or are neurodevelopmental features of a premutation phenotype, is uncertain, although some imaging data suggest that both are possibilities [89]. Also unclear is whether cognitive problems precede, follow, or are contemporaneous with the onset of tremor and ataxia, and whether these may be associated with neuropathologic and/or neuroradiologic anomalies. Neurophysiologic and neuroimaging data, in conjunction with neuropsychological examination, may help to answer this question.

\footnotetext{
Abbreviations

AD: Alzheimer's disease; EF: executive functioning; ERP: event-related potential; FMR1: fragile $X$ mental retardation 1; FMRP: fragile $X$ mental retardation protein; FX: fragile $X$; FXS: fragile $X$ syndrome; FXTAS: fragile $X$-associated tremor/ataxia syndrome; IPS: intraparietal sulcus; IQ: intelligence quotient; MRI: magnetic resonance imaging; WAIS: Wechsler Adult Intelligence Scale.
} 


\section{Competing interests}

The authors declare that they have no competing interests.

\section{Authors' contributions}

All authors contributed to the writing of this review. All authors read and approved the final manuscript.

\section{Author details}

${ }^{1}$ Department of Psychology, University of Colorado Denver, Denver, CO, USA. ${ }^{2}$ Department of Medicine; Division of Health Care Policy and Research, University of Colorado School of Medicine, Aurora, CO, USA. ${ }^{3}$ School of Psychology \& Psychiatry; Faculty of Medicine, Nursing and Health Sciences, Monash University, Melbourne, Victoria, Australia. ${ }^{4}$ Olga Tennison Autism Research Centre, School of Psychological Science, La Trobe University, Melbourne, Victoria, Australia. ${ }^{5}$ Center for Mind and Brain, University of California, Davis, CA, USA. ${ }^{6}$ Department of Neurology, University of California, Davis, Sacramento, CA, USA. 7 Department of Psychology, University of California-Davis, Sacramento, CA, USA. ${ }^{8}$ MIND Institute, University of California-Davis Medical Center, Sacramento, CA, USA. ${ }^{9}$ Department of Human Genetics, Emory University, Atlanta, GA, USA. ${ }^{10}$ Department of Pediatrics, University of California, Davis, Sacramento, CA, USA.

\section{Received: 31 October 2013 Accepted: 27 January 2014}

Published: 30 July 2014

\section{References}

1. Hagerman RJ, Leehey M, Heinrichs W, Tassone F, Wilson R, Hills J, Grigsby J, Gage B, Hagerman PJ: Intention tremor, Parkinsonism and generalized brain atrophy in older male carriers of fragile X. Neurology 2001, 57:127-130

2. Grigsby J, Brega AG, Jacquemont S, Loesch DZ, Leehey MA, Goodrich GK, Hagerman RJ, Epstein J, Wilson R, Cogswell JB, Jardini T, Hagerman PJ: Impairment in the cognitive functioning of men with Fragile $X$ Tremor-Ataxia Syndrome (FXTAS). J Neurol Sci 2006, 248:227-233.

3. Grigsby J, Brega AG, Leehey MA, Goodrich GK, Jacquemont S, Loesch DZ, Cogswell JB, Epstein J, Wilson R, Jardini T, Gould E, Bennett RE, Hessl D, Cohen S, Cook K, Tassone F, Hagerman PJ, Hagerman RJ: Impairment of executive cognitive functioning in males with fragile $\mathrm{X}$-associated tremor/ataxia syndrome (FXTAS). Mov Disord 2007, 22:645-650.

4. Grigsby J, Brega AG, Engle K, Leehey MA, Hagerman RJ, Tassone F, Hessl D, Hagerman PJ, Cogswell JB, Bennett RE, Cook K, Hall DA, Bounds LS, Paulich $\mathrm{MJ}$, Reynolds $\mathrm{A}$ : Cognitive profile of fragile $\mathrm{X}$ premutation carriers with and without fragile $\mathrm{X}$-associated tremor/ataxia syndrome. Neuropsychology 2008, 22:48-60.

5. Brega AG, Goodrich G, Bennett RE, Hessl D, Engle K, Leehey MA, Bounds LS, Paulich MJ, Hagerman RJ, Hagerman PJ, Cogswell JB, Tassone F, Reynolds A, Kooken R, Kenny M, Grigsby J: The primary cognitive deficit among males with fragile X-associated tremor/ataxia syndrome (FXTAS) is a dysexecutive syndrome. J Clin Exp Neuropsychol 2008, 30:853-869.

6. Fuster JM: Executive frontal functions. Exp Brain Res 2000, 133:66-70

7. Quintana J, Fuster JM: From perception to action: temporal integrative functions of prefrontal and parietal neurons. Cereb Cortex 1999, 9:213-221.

8. Grigsby J, Leehey MA, Jacquemont S, Brunberg JA, Hagerman RJ, Wilson R, Epstein JH, Greco CM, Tassone F, Hagerman PJ: Cognitive impairment in a 65-year-old male with fragile X-associated tremor-ataxia syndrome (FXTAS). Cogn Behav Neurol 2006, 19:165-171.

9. Folstein MF, Folstein SE, McHugh PR: "Mini-mental state". A practical method for grading the cognitive state of patients for the clinician. J Psychatr Res 1975, 12:189-198.

10. Seritan AL, Nguyen DV, Tomaszewski F, Hinton LW, Grigsby J, Bourgeois JA, Hagerman R: Dementia in fragile X-associated tremor/ataxia syndrome (FXTAS): Comparison with Alzheimer's Disease. Am J Med Genet Part B: Neuropsychiatr Genet 2008, 147B:1138-1144.

11. Seritan A, Cogswell J, Grigsby J: Cognitive dysfunction in FMR1 premutation carriers. Curr Psychiatr Rev 2012, 9:78-84.

12. Brega AG, Reynolds A, Bennet RE, Leehey MA, Bounds LS, Cogswell JB, Hagerman RJ, Hagerman PJ, Grigsby J: Functional status of men with the fragile $X$ premutation, with and without the tremor/ataxia syndrome (FXTAS). Int J Geriatr Psychiat 2009, 24:1101-1109.
13. Yang JC, Chan SH, Khan S, Schneider A, Nanakul R, Teichholtz S, Niu YQ, Seritan A, Tassone F, Grigsby J, Hagerman PJ, Hagerman RJ, Olichney JM: Neural substrates of executive dysfunction in fragile X-associated tremor/ataxia syndrome (FXTAS): a brain potential study. Cereb Cortex 2012, 23:2657-2666.

14. Yang JC, Simon C, Niu YQ, Bogost M, Schneider A, Tassone F, Seritan A, Grigsby J, Hagerman PJ, Hagerman RJ, Olichney JM: Phenotypes of hypofrontality in older female fragile $\mathrm{X}$ premutation carriers. Ann Neurol 2013, 74:275-283.

15. Schmahmann JD: Disorders of the cerebellum: ataxia, dysmetria of thought, and the cerebellar cognitive affective syndrome. J Neuropsychiatry Clin Neurosci 2004, 16:367-378.

16. Schmahmann JD, Smith EE, Eichler FS, Filley CM: Cerebral white matter: Neuroanatomy, clinical neurology, and neurobehavioral correlates. Ann N Y Acad Sci 2008, 1142:266-309.

17. Greco CM, Berman RF, Martin RM, Tassone F, Schwartz PH, Brunberg JA, Grigsby J, Hessl D, Becker EJ, Papazian J, Leehey MA, Hagerman RJ, Hagerman PJ: Neuropathology of fragile X-associated tremor-ataxia syndrome (FXTAS). Brain 2006, 129:243-255.

18. Brunberg JA, Jacquemont S, Hagerman RJ, Berry-Kravis EM, Grigsby J, Leehey MA, Tassone F, Brown WT, Greco C, Hagerman PJ: Fragile X premutation carriers: characteristic MR imaging findings in adult males with progressive cerebellar and cognitive dysfunction. Am J Neuroradiol 2002, 23:1757-1766.

19. Cohen S, Masyn K, Adams J, Hessl D, River S, Tassone F, Brunberg J, DeCarli C, Zhang L, Cogswell J, Loesch D, Leehey M, Grigsby J, Hagerman PJ, Hagerman R: Molecular and imaging correlates of the fragile $X$-associated tremor ataxia syndrome (FXTAS). Neurology 2006, 67:1426-1431.

20. Filley CM, Franklin GM, Heaton RK, Rosenberg NL: White matter dementia: clinical disorders and implications. Neuropsychiatry Neuropsychol Behav Neurol 1988, 1:239-254.

21. Filley CM: The behavioral neurology of cerebral white matter. Neurology 1998, 50:1535-1540.

22. Tullberg M, Fletcher E, DeCarli C, Mungas D, Reed BR, Harvey DJ, Weiner MW, Chui HC, Jagust WJ: White matter lesions impair frontal lobe function regardless of their location. Neurology 2004, 63:246-253.

23. Coffey SM, Cook K, Tartaglia N, Tassone F, Nguyen DV, Pan R, Bronsky HE, Yuhas J, Borodyanskaya M, Grigsby J, Doerflinger M, Hagerman PJ, Hagerman RJ: Expanded clinical phenotype of women with the FMR1 premutation. Am J Med Genet A 2008, 146A:1009-1016.

24. Rodriguez-Revenga L, Madrigal I, Pagonabarraga J, Xuncla M, Badenas C, Kulisevsky J, Gomez B, Mila M: Penetrance of FMR1 premutation associated pathologies in fragile X syndrome families. Eur J Hum Genet 2009, 17:1359-1362.

25. Adams JS, Adams PE, Nguyen D, Brunberg JA, Tassone F, Zhang W, Koldewyn K, Rivera SM, Grigsby J, Zhang L, DeCarli C, Hagerman PJ, Hagerman RJ: Volumetric brain changes in females with fragile $\mathrm{X}$-associated tremor/ataxia syndrome (FXTAS). Neurology 2007, 2007(69):851-859.

26. Apartis E, Blancher A, Meissner WG, Guyant-Marechal L, Maltete D, De Broucker T, Legrand AP, Bouzenada H, Thanh HT, Sallansonnet-Froment M, Wang A, Tison F, Roué-Jagot C, Sedel F, Charles P, Whalen S, Héron D, Thobois S, Poisson A, Lesca G, Ouvrard-Hernandez AM, Fraix V, Palfi S, Habert MO, Gaymard B, Dussaule JC, Pollak P, Vidailhet M, Durr A, Barbot JC, et al: FXTAS: new insights and the need for revised diagnostic criteria. Neurology 2012, 79:1898-1907.

27. Berry-Kravis E, Lewin F, Wuu J, Leehey M, Hagerman R, Hagerman P, Goetz CG: Tremor and ataxia in fragile $X$ premutation carriers: blinded videotape study. Ann Neurol 2003, 53:616-623.

28. Berry-Kravis E, Abrams L, Coffey SM, Hall DA, Greco C, Gane LW, Grigsby J, Bourgeois J, Finucane B, Jacquemont S, Brunberg JA, Zhang L, Lin J, Tassone F, Hagerman PJ, Hagerman RJ, Leehey MA: Fragile X-associated tremor/ataxia syndrome: clinical features, genetics, and testing guidelines. Mov Disord 2007, 22:2018-2030.

29. Jacquemont S, Hagerman RJ, Leehey M, Grigsby J, Zhang L, Brunberg JA Greco C, Des Portes V, Jardini T, Levine R, Berry-Kravis E, Brown WT, Schaeffer S, Kissel J, Tassone F, Hagerman PJ: Fragile X premutation tremor/ataxia syndrome: molecular, clinical, and neuroimaging correlates. Am J Hum Genet 2003, 72:869-878.

30. Hagerman RJ, Leavitt BR, Farzin F, Jacquemont S, Greco CM, Brunberg JA, Tassone F, Hessl D, Harris SW, Zhang L, Jardini T, Gane LW, Ferranti J, Ruiz L, Leehey MA, Grigsby J, Hagerman PJ: Fragile-X-associated tremor/ataxia 
syndrome (FXTAS) in females with the FMR1 premutation. Am J Hum Genet 2004, 74:1051-1056.

31. Jacquemont S, Hagerman RJ, Leehey MA, Hall DA, Levine RA, Brunberg JA, Zhang L, Jardini T, Gane LW, Harris SW, Herman K, Grigsby J, Greco CM, Berry-Kravis E, Tassone F, Hagerman PJ: Penetrance of the fragile $\mathrm{X}$-associated tremor/ataxia syndrome in a premutation carrier population. JAMA 2004, 291:460-469.

32. Yang JC, Simon C, Niu YQ, Bogost M, Schneider A, Tassone F, Seritan A, Grigsby J, Hagerman PJ, Hagerman RJ, Olichney JM: Phenotypes of hypofrontality in older female fragile X premutation carriers. Ann Neurol 2013, 20:23933.

33. Sterling AM, Mailick M, Greenberg J, Warren SF, Brady N: Language dysfluencies in females with the FMR1 premutation. Brain Cogn 2013, 82:84-89.

34. Tassone F, Greco CM, Hunsaker MR, Seritan AL, Berman RF, Gane LW, Jacquemont S, Basuta K, Jin LW, Hagerman PJ, Hagerman RJ: Neuropathological, clinical and molecular pathology in female fragile $X$ premutation carriers with and without FXTAS. Genes Brain Behav 2012, 11:577-585.

35. Adams PE, Adams JS, Nguyen DV, Hessl D, Brunberg JA, Tassone F, Zhang W, Koldewyn K, Rivera SM, Grigsby J, Zhang L, DeCarli C, Hagerman PJ, Hagerman RJ: Psychological symptoms correlate with reduced hippocampal volume in fragile $\mathrm{X}$ premutation carriers. Am J Med Genet B Neuropsychiatr Genet 2009, 153B:775-785.

36. Hunter JE, Rohr JK, Sherman SL: Co-occurring diagnoses among FMR1 premutation allele carriers. Clin Genet 2010, 77:374-381.

37. Kraan C, Hocking DR, Georgiou-Karistianis N, Metcalfe S, Archibald A, Fielding J, Trollor J, Bradshaw JL, Cohen J, Cornish K: Impaired response inhibition is associated with self-reported symptoms of depression, anxiety and ADHD in female FMR1 premutation carriers. AJMG 2013, 165:41-51.

38. Hunter JE, Allen EG, Abramowitz A, Rusin M, Leslie M, Novak G, Hamilton D, Shubeck L, Charen K, Sherman SL: Investigation of phenotypes associated with mood and anxiety among male and female fragile $\mathrm{X}$ premutation carriers. Behav Genet 2008, 38:493-502.

39. Lachiewicz A, Dawson D, Spiridigliozzi G, Cuccaro M, Lachiewicz M, McConkie-Rosell A: Indicators of anxiety and depression in women with the fragile $X$ premutation: assessment of a clinical sample. I Intellect Disabil Res 2010, 54:597-610.

40. Roberts JE, Bailey DB Jr, Mankowski J, Ford A, Sideris J, Weisenfeld LA, Heath TM, Golden RN: Mood and anxiety disorders in females with the FMR1 premutation. Am J Med Genet B Neuropsychiatr Genet 2009, 150B:130-139.

41. Nunez PL, Srinivasan R: Electric Fields of the Brain: the Neurophysics of EEG. 2nd edition. New York, NY: Oxford University Press; 2006:163-166.

42. Olichney JM, Chan S, Wong LM, Schneider A, Seritan A, Niese A, Yang JC Laird K, Teichholtz S, Khan S, Tassone F, Hagerman R: Abnormal N400 word repetition effects in fragile $\mathrm{X}$-associated tremor/ataxia syndrome. Brain 2010, 133:1438-1450.

43. Olichney JM, Iragui VJ, Salmon DP, Riggins BR, Morris SK, Kutas M: Absent event-related potential (ERP) word repetition effects in mild Alzheimer's disease. Clin Neurophysiol 2006, 117:1319-1330.

44. Olichney JM, Taylor JR, Gatherwright J, Salmon DP, Bressler AJ, Kutas M, Iragui-Madoz VJ: Patients with $\mathrm{MCl}$ and N400 or P600 abnormalities are at very high risk for conversion to dementia. Neurology 2008, 70:1763-1770

45. Yang JC, Simon C, Schneider A, Hamilton H, Hagerman PJ, Hagerman RJ JM: Abnormal Semantic Processing and Episodic Memory in Females with Fragile $X$-associated Tremor/Ataxia Syndrome (FXTAS) [abstract]. Hawaii: The 41st International Neuropsychological Society (INS) annual meeting, Feb 2-6; 2013

46. Grunwald T, Beck H, Lehnertz K, Blümcke I, Pezer N, Kurthen M, Fernández G, Van Roost D, Heinze HJ, Kutas M, Elger CE: Evidence relating human verbal memory to hippocampal $\mathrm{N}$-methyl-D-aspartate receptors. Proc Natl Acad Sci U S A 1999, 96:12085-12089.

47. Yang JC, Simon C, Niu YQ, Chen L, Seritan A, Schneider A, Hagerman PJ, Hagerman RJ, Olichney JM: Effects of Memantine on Language/Memoryrelated Brain Potentials in Fragile X-associated Tremor/Ataxia Syndrome (FXTAS). Perugia, Italy: The 1st International Conference on FMR1 Premutation: Basic Mechanisms and Clinical Involvement; 2013.

48. Seritan AL, Nguyen DV, Mu Y, Tassone F, Bourgeois JA, Schneider A, Cogswell J, Cook K, Leehey M, Grigsby J, Olichney JM, Adams P, Legg W, Zhang L, Hagerman PJ, Hagerman RJ: Memantine for fragile X-associated tremor/ataxia syndrome (FXTAS): a randomized, double-blind, placebo-controlled trial. J Clin Psychiatry. in press.

49. Karmon $Y$, Gadoth N: Fragile $X$ associated tremor/ataxia syndrome (FXTAS) with dementia in a female harbouring FMR1 premutation. J Neurol Neurosurg Psychiatry 2008, 79:738-739.

50. Schneider A, Ballinger E, Chavez A, Tassone F, Hagerman RJ, Hessl D: Prepulse inhibition in patients with fragile $\mathrm{X}$-associated tremor ataxia syndrome. Neurobiol Aging 2012, 33:1045-1053.

51. Cornish, Hocking DR, MosS SA, Kogan CS: Selective executive markers of at-risk profiles associated with the fragile X premutation. Neurology 2011, 77:618-622.

52. Cornish, Kogan CS, Li L, Turk J, Jacquemont S, Hagerman RJ: Lifespan changes in working memory in fragile X premutation males. Brain Cogn 2009, 69:551-558.

53. Cornish K, Li L, Kogan CS, Jacquemont S, Turk J, Dalton A, Hagerman RJ, Hagerman PJ: Age-dependent cognitive changes in carriers of the fragile $X$ syndrome. Cortex 2008, 44:628-636.

54. Wechsler D: WMS-Ill: Wechsler Memory Scale-Third Edition. San Antonio: Psychological Corporation; 1997.

55. Hashimoto RI, Backer KC, Tassone F, Hagerman RJ, Rivera SM: An fMRI study of the prefrontal activity during the performance of a working memory task in premutation carriers of the fragile $\mathrm{X}$ mental retardation 1 gene with and without fragile X-associated tremor/ataxia syndrome (FXTAS). J Psychiatr Res 2011, 45:36-43.

56. Hunter JE, Abramowitz A, Rusin M, Sherman SL: Is there evidence for neuropsychological and neurobehavioral phenotypes among adults without FXTAS who carry the FMR1 premutation? A review of current literature. Genet Med 2009, 11:79-89.

57. Hunter JE, Allen EG, Abramowitz A, Rusin M, Leslie M, Novak G, Hamilton D, Shubeck L, Charen K, Sherman SL: No evidence for a difference in neuropsychological profile among carriers and noncarriers of the FMR1 premutation in adults under the age of 50. Am J Hum Genet 2008, 83:692-702.

58. Hunter JE, Sherman SL, Grigsby J, Kogan CS, Cornish K: Capturing the fragile $\mathrm{X}$ premutation phenotypes: a collaborative effort across multiple cohorts. Neuropsychologia 2012, 26:156-164.

59. Cornish K, Kogan C, Turk J, Manly T, James N, Mills A, Dalton A: The emerging fragile $X$ premutation phenotype: evidence from the domain of social cognition. Brain Cogn 2005, 57:53-60.

60. Dorn MB, Mazzocco MM, Hagerman RJ: Behavioral and psychiatric disorders in adult male carriers of fragile X. J Am Acad Child Adolesc Psychiatry 1994, 33:256-264.

61. Moore CJ, Daly EM, Schmitz N, Tassone F, Tysoe C, Hagerman RJ, Hagerman PJ, Morris RG, Murphy KC, Murphy DGM: A neuropsychological investigation of male premutation carriers of fragile $\mathrm{X}$ syndrome. Neuropsychologia 2004, 42:1934-1947.

62. Loesch D, Bui QM, Grigsby J, Butler E, Epstein JH, Huggins RM, Taylor AK, Hagerman RJ: Effect of the fragile $X$ status categories and the FMRP levels on executive functioning in fragile $X$ males and females. Neuropsychology 2003, 17:646-657.

63. Goodrich-Hunsaker NJ, Wong LM, McLennan Y, Srivastava S, Tassone F, Harvey D, Rivera SM, Simon TJ: Young adult female fragile X premutation carriers show age- and genetically-modulated cognitive impairments. Brain Cogn 2011, 75:255-260.

64. Goodrich-Hunsaker NJ, Wong LM, McLennan Y, Tassone F, Harvey D, Rivera SM, Simon TJ: Adult female fragile $X$ premutation carriers exhibit age- and CGG repeat length-related impairments on an attentionally based enumeration task. Front Hum Neurosci 2011, 5:14.

65. Lachiewicz AM, Dawson DV, Spiridigliozzi GA, McConkie-Rosell A: Arithmetic difficulties in females with the fragile $X$ premutation. Am J Med Genet $A$ 2006, 140:665-672

66. Semenza C, Bonollo S, Polli R, Busana C, Pignatti R, luculano T, Maria Laverda A, Priftis K, Murgia A: Genetics and mathematics: FMR1 premutation female carriers. Neuropsychologia 2012, 50:3757-3763.

67. Kraan CM, Hocking DR, Bradshaw JL, Fielding J, Cohen J, GeorgiouKaristianis N, Cornish KM: Neurobehavioural evidence for the involvement of the FMR1 gene in female carriers of fragile $\mathrm{X}$ syndrome. Neurosci Biobehav Rev 2013, 37:522-547.

68. Goodrich-Hunsaker NJ, Wong LM, McLennan Y, Tassone F, Harvey D, Rivera $\mathrm{S}$, Simon TJ: Enhanced manual and oral motor reaction time in young adult female fragile X premutation carriers. J Int Neuropsychol Soc 2011, $17: 1-5$. 
69. Steyaert J, Borghgraef M, Fryns JP: Apparently enhanced visual information processing in female fragile $\mathrm{X}$ carriers: preliminary findings. Am J Med Genet 1994, 51:374-377.

70. Chonchaiya W, Nguyen DV, Au J, Campos L, Berry-Kravis EM, Lohse K, Mu Y, Utari A, Hervey C, Wang L, Sorensen P, Cook K, Gane L, Tassone F, Hagerman RJ: Clinical involvement in daughters of men with fragile X-associated tremor ataxia syndrome. Clin Genet 2010, 78:38-46.

71. Narcisa V, Aguilar D, Nguyen DV, Campos L, Brodovsky J, White S, Adams P, Tassone F, Hagerman PJ, Hagerman RJ: A quantitative assessment of tremor and ataxia in female FMR1 premutation carriers using CATSYS. Curr Gerontol Geriatr Res 2011, 484713:8.

72. Kraan CM, Hocking DR, Georgiou-Karistianis N, Metcalfe SA, Archibald AD, Fielding J, Trollor J, Bradshaw JL, Cohen J, Cornish KM: Cognitive-motor interference during postural control indicates at-risk cerebellar profiles in females with the FMR1 premutation. Behav Brain Res 2013, 26:00432-00434.

73. Bailey DB Jr, Raspa M, Olmsted M, Holiday DB: Co-occurring conditions associated with FMR1 gene variations: findings from a national parent survey. Am J Med Genet A 2008, 146A:2060-2069.

74. Johnston C, Eliez S, Dyer-Friedman J, Hessl D, Glaser B, Blasey C, Taylor A, Reiss A: Neurobehavioral phenotype in carriers of the fragile $X$ premutation. Am J Med Genet 2001, 103:314-319.

75. Hunter JE, Leslie M, Novak G, Hamilton D, Shubeck L, Charen K, Abramowitz A, Epstein MP, Lori A, Binder E, Cubells JF, Sherman SL: Depression and anxiety symptoms among women who carry the FMR1 premutation: impact of raising a child with fragile $X$ syndrome is moderated by CRHR1 polymorphisms. Am J Med Genet B Neuropsychiatr Genet 2012, 159B:549-559.

76. Seltzer MM, Barker ET, Greenberg JS, Hong J, Coe C, Almeida D: Differential sensitivity to life stress in FMR1 premutation carrier mothers of children with fragile X syndrome. Health Psychol 2012, 31:612-622.

77. Kenna HA, Tartter M, Hall SS, Lightbody AA, Nguyen Q, De Los Angeles CP, Reiss AL, Rasgon NL: High rates of comorbid depressive and anxiety disorders among women with premutation of the FMR1 gene. Am J Med Genet B Neuropsychiatr Genet 2013, 3:32196.

78. Zangenehpour S, Cornish KM, Chaudhuri A: Whole-brain expression analysis of FMRP in adult monkey and its relationship to cognitive deficits in fragile X syndrome. Brain Res 2009, 1264:76-84.

79. Tassone F, Hagerman RJ, Garcia-Arocena D, Khandjian EW, Greco CM, Hagerman PJ: Intranuclear inclusions in neural cells with premutation alleles in fragile X associated tremor/ataxia syndrome. J Med Genet 2004, 41:e43.

80. Hashimoto R, Javan AK, Tassone F, Hagerman RJ, Rivera SM: A voxel-based morphometry study of grey matter loss in fragile X-associated tremor/ ataxia syndrome. Brain 2011, 134:863-78.

81. Koldewyn K, Hessl D, Adams J, Tassone F, Hagerman PJ, Hagerman RJ, Rivera SM: Reduced hippocampal activation during recall is associated with elevated FMR1 mRNA and psychiatric symptoms in men with the fragile X premutation. Brain Imaging Behav 2008, 2:105-116.

82. Kim SY, Hashimoto RI, Tassone F, Simon TJ, Rivera SM: Altered neural activity of magnitude estimation processing in adults with the fragile $X$ premutation. J Psychiatr Res 2013, 47:1909-1916.

83. Hagerman P: Current gaps in understanding the molecular basis of FXTAS. Tremor Other Hyperkinet Mov 2012, 2. http://tremorjournal.org/ article/view/63.

84. Tassone F, Adams J, Berry-Kravis EM, Cohen SS, Brusco A, Leehey MA, LI L, Hagerman RJ, Hagerman PJ: CGG repeat length correlates with age of onset of motor signs of the fragile $\mathrm{X}$-associated tremor/ataxia syndrome (FXTAS). Am J Med Genet B Neuropsychiat Genet 2007, 144B:566-569.

85. Leehey MA, Berry-Kravis E, Goetz CG, Zhang L, Hall DA, Li L, Rice CD, Lara R, Cogswell J, Reynolds A, Gane L, Jacquemont S, Tassone F, Grigsby J, Hagerman R, Hagerman PJ: FMR1 CGG repeat length predicts motor dysfunction in premutation carriers. Neurology 2008, 70:1397-1402.

86. Bourgeois JB, Farzin F, Brunberg JA, Tassone F, Hagerman P, Zhang L, Hess $D$, Hagerman R: Dementia with mood symptoms in a fragile $X$ premutation carrier with the fragile $\mathrm{X}$-associated tremor/ataxia syndrome: clinical intervention with donepezil and venlafaxine. J Neuropsychiatry Clin Neurosci 2006, 18:171-177.

87. Hagerman RJ, Hall DA, Coffey S, Leehey M, Bourgeois J, Gould J, Zhang L, Seritan A, Berry-Kravis E, Olichney J, Miller JW, Fong AL, Carpenter R, Bodine C, Gane LW, Rainin E, Hagerman H, Hagerman PJ: Treatment of fragile
X-associated tremor ataxia syndrome (FXTAS) and related neurological problems. Clin Interv Aging 2008, 3:251-262.

88. Leehey MA: Fragile $\mathrm{X}$-associated tremor/ataxia syndrome: clinical phenotype, diagnosis, and treatment. J Investig Med 2009, 57:830-836.

89. Battistella G, Niederhauser J, Fornari E, Hippolyte L, Perrin AG, Lesca G, Forzano F, Hagmann P, Vingerhoets FJG, Draganski B, Maeder P, Jacquemont $S$ : Brain structure in asymptomatic FMR1 premutation carriers at risk for fragile $\mathrm{X}$-associated tremor/ataxia syndrome. Neurobiol Aging 2013, 34:1700-1707.

doi:10.1186/1866-1955-6-28

Cite this article as: Grigsby et al:: The cognitive neuropsychological phenotype of carriers of the FMR1 premutation. Journal of Neurodevelopmental Disorders 2014 6:28.

\section{Submit your next manuscript to BioMed Central and take full advantage of:}

- Convenient online submission

- Thorough peer review

- No space constraints or color figure charges

- Immediate publication on acceptance

- Inclusion in PubMed, CAS, Scopus and Google Scholar

- Research which is freely available for redistribution

Submit your manuscript at www.biomedcentral.com/submit
C Biomed Central 